\title{
Effect of Organic and Inorganic Fertilizers on Growth, Yield and Quality Attributes of Hybrid bitter gourd (Momordica charantia L.)
}

\author{
Sangeeta Shree*, Champa Lal Regar, Fiza Ahmad, Vijay Kumar Singh, \\ Ritu Kumari and Amrita Kumari
}

Department of Horticulture (Vegetable and Floriculture), BAU, Sabour-813210, India

*Corresponding author

\begin{tabular}{|l|}
\hline Key w or d s \\
Yield, Quality, \\
Bitter gourd, INM \\
\hline Article Info \\
\hline Accepted: \\
20 March 2018 \\
Available Online: \\
10 April 2018 \\
\hline
\end{tabular}

\section{A B S T R A C T}

Bitter gourd (Momordica charantia L.) is popular vegetable because of its rich nutritive value, high productivity and easy package of practices which respond favourably to application of different soil organic amendments like vermicompost. In this experiment it was designed to evaluate the effect of different combinations of organic (vermicompost) and inorganic (NPK) source of nutrients on growth, yield and quality of bitter gourd. The application of vermicompost @ $4.68 \mathrm{t} \mathrm{ha}^{-1}$ recorded $3.99 \mathrm{~kg} /$ fruits per vine with an average fruit weight of $62.18 \mathrm{~g} /$ fruit. Application of NPK @ 100:60:50 kg ha ${ }^{-1}$ recorded maximum fruit yield/vine $(3.64 \mathrm{~kg})$ and with average fruit weight $56.75 \mathrm{~g} /$ fruit. Interaction effect of vermicompost @ 4.68 t ha ${ }^{-1}$ and inorganic fertilizer, NPK @ 50:30:25 kg ha ${ }^{-1}$ was found to be best treatment combination for yield and yield attributing traits and as well as for benefit cost ratios. The maximum yield i.e. $36.81 \mathrm{t} \mathrm{ha}^{-1}$ was found under the combined use of vermicompost@ $4.68 \mathrm{t} \mathrm{ha}^{-1}$ and inorganic fertilizer@ 50:30:25 kg ha ${ }^{-1}$. It was also observed that some of the quality attributes like TSS ( ${ }^{\circ}$ Brix), Zn and Fe content of the fruit were significantly influenced with the application of different levels of vermicompost while vitamin $\mathrm{C}$ and $\mathrm{Fe}$ were significantly affected with the application of both organic and inorganic fertilizers in different combinations.

\section{Introduction}

Bitter gourd (Momordica charantia L.) is a tropical and subtropical vegetable crop of the family cucurbitaceae. Bitter gourd is a leading vegetable crop of India, the higher yield and maximum returns make it the most preferred vegetable crop of Indian farmers (Naveen et al., 2012). Fruits are considered as a rich source of vitamins and minerals and are rich in vitamin C $(88 \mathrm{mg} / 100 \mathrm{~g})$.It possesses antioxidant, antimicrobial, antiviral, antihepatotoxic, anti ulcerogenic properties and also have the ability to lower blood sugar (Behera, 2011).

It has great demand in domestic and international market among fresh vegetables due to its hypoglycaemic property. Leading states growing the crop are Andhra Pradesh followed by Odisha, Bihar, Chhattisgarh and Madhya Pradesh. It is grown both in rainy season and as well in spring summer season. Fruits vary in shapes, size, colour and bitterness. A numbers of varieties and hybrids have been recommended by the government 
institute as well as by private companies. Hybrids have an edge over the varieties owing to its higher yield potential and robust nature. Bitter gourd hybrids respond well to manure and fertilizer applications. However, continuous use of the heavy doses of fertilizers damage the natural ecology and adversely affects the nutrient recycling and the biological communities in soil which otherwise support the crop production (Prasad et al., 2009). Therefore, it is being increasingly realized that organic manure is the cheapest eco-friendly resource for providing nutrients to crop plant and helps in curtailing the use of chemical fertilizers. Manures not only supply plant nutrients but also add organic matter, which improve physical condition of soil (Lundwick and Johnston, 2002). Among various sources of organic manures, vermicompost have been recognized as having considerable potential as soil amendments. Therefore, it is necessary to explore the potential of vermicompost and possibility of supplementing chemical fertilizer. The vermicompost has been found to be an ideal organic source of nutrient as, it is rich in macro and micro nutrient and helps to increase yield (Hidalgo and Pashanasi et al., 1999). Therefore the present study was designed to evaluate the effect of different combinations of organic (vermicompost) and inorganic (NPK) source of nutrients on growth, yield and quality of bitter gourd and also on the economics of bitter gourd production.

\section{Materials and Methods}

The experiment was carried out at vegetable research farm of Bihar Agricultural University, Sabour, Bhagalpur to study the effect of inorganic and organic fertilizers on growth, yield and quality attributes of bitter gourd (Momordica charantia L). The climate of this place is tropical to subtropical and slightly semi-arid in nature and is characterized by very dry summer, moderate rainfall and very cold winter. December and January are usually the coldest months, where May and June are the hottest months. The major rainfall precipitates generally between June and October. The details of meteorological observations recorded as monthly maximum and minimum temperature and rainfall from January to June 2012 collected form agro-meteorological observatory, Bihar Agricultural College, Sabour, Bhagalpur have been depicted graphically in Figure 1 and 2. The weather conditions prevailing during the period of investigation was close to the normal for the place and could be termed congenial for the growth and development of bitter gourd hybrid, Varun. The soil of the experimental plot was Indo-Gangetic alluvial in origin. The land was fairly levelled and well drained. The soil of the experimental plot was sandy loam in texture and medium in fertility. The soil reaction was in the neutral range exhibiting suitability for cultivation of bitter gourd. The design of experiment was RBD (factorial).A bitter gourd hybrid, Varun was used as experimental material. Varun is a $F_{1}$ hybrid developed by Bharti Seeds Pvt. Ltd. and is recommended for sub-tropical a zone which is grown in local Bhagalpur area. Its fruit is medium size, green, attractive and high yielding. There were nine treatments replicated thrice. Treatment wise different organic manures were applied before sowing of seeds and mixed in the soil. One third dose of nitrogen as urea with full dose of phosphorus $\left(\mathrm{P}_{2} \mathrm{O}_{5}\right)$ as DAP, potash $\left(\mathrm{K}_{2} \mathrm{O}\right)$ as murate of potash and vermicompost were applied before sowing of seeds as per pit, in commensuration with treatments specifications (Table 1).

The desired amount of fertilizers and vermicompost as per treatments was mixed thoroughly and the mixture was placed in the top 6-20 $\mathrm{cm}$ layer of soil pit. After 
incorporation of the fertilizers mixture, seeds were sown next day after irrigation. The remaining two third dose of nitrogen was applied in two split doses at an interval of twenty five and forty five days after sowing of seeds.

Tagged plants were used for recording various observations. The observations recorded for the aforesaid five plants were worked out to give means in respect of growth, yield and quality parameters, which were utilized in statistical analysis by the method of analysis of the variance prescribed by Panse and Sukhatme (1978). Comparison of the treatments was made with the help of critical differences (CD).

\section{Results and Discussion}

The morphological characters of bitter gourd crop namely, length of main vine $(\mathrm{m})$, number of branches per vine, days to first female flower emergence, node number to first female flower emergence, days taken to first fruit picking, number of fruit per vine, fruit length $(\mathrm{cm})$, fruit girth $(\mathrm{cm})$, fruit weight per vine $(\mathrm{kg})$, average fruit weight $(\mathrm{g})$, yield $\mathrm{tha}^{-1}$ were influenced by the combined application of NPK and vermicompost. Application of only $100 \%$ chemical fertilizers or $100 \%$ vemicompost alone could not influence the growth or the yield characters significantly as compared to combined application. The data pertaining to the various observations on growth and quality parameters in bitter gourd have been show in Table 2 and that regarding yield and economics in Table 3. Application of vermicompost 100 per cent brought significantly increased length of main vine $(4.03 \mathrm{~m})$ and number of branches (8.72) per plant, number of fruits (62.86), fruit length $(13.97 \mathrm{~cm})$, fruit girth $(8.44 \mathrm{~cm})$, average fruit weight $(62.18 \mathrm{~g})$, fruit yield $\left(3.99 \mathrm{~kg}\right.$ vine $\left.^{-1}\right)$ and also the yield (31.91t). These findings are in consonance with the earlier studies of Arancon et al., (2006), Prabha et al., (2007),
Narkhede et al., (2011). All the yield parameters and yield improved due to the application of higher dose of vermicompost because, vermicompost provided better nutrition status by improving the physical, biological and chemical properties of soil.

Vermicompost might have reduced the soil compactness and improved soil aeration which helped in better root development resulting deep penetration of root system which facilitated better absorption of water as well as nutrient. Present finding is in agreement with the findings of Renukaand Ravi Shankar (2001) in tomato, Sreenivas et al., (2000) in brinjal and Reddy and Rao (2004) in bitter gourd, Azarmi et al., (2008) in Tomato.

Application of vermicompost 100 per cent significantly decreased the number of nodes (13.23) to first female flower appearance, days (49.48) to first female flower emergence and days (59.30) to first fruit picking and was followed by vermicompost 75 percent and vermicompost 50 per cent in all the cases. The earliness might be also due to the enhanced production of growth promoting substances like gibbrelic acid, IAA by application of vermicompost which induce the earliness of female flower production, more flower stalks resulting early fruit harvesting. The similar findings have also been made observed by Sreenivas et al., (2000) and Kameswari et al., (2010).Total soluble solids (TSS) and Vitamin ' $\mathrm{C}$ ' increased progressively with the vermicompost@100 per cent because bitter gourd responded favourably to application of organic amendment like vermicompost and this enhanced the antioxidant (vitamin C) content of the leaves and fruits (Marilou et al., 2012). Vermicompost released nutrient in soil and provided favorable condition in the plant root zone resulting higher absorption or uptake of major as well as minor nutrient which might have directly related to concentration of T.S.S. in fruits. 
Fig.1 Temperature $\left({ }^{0} \mathrm{C}\right)$ during experimental period in the year 2012

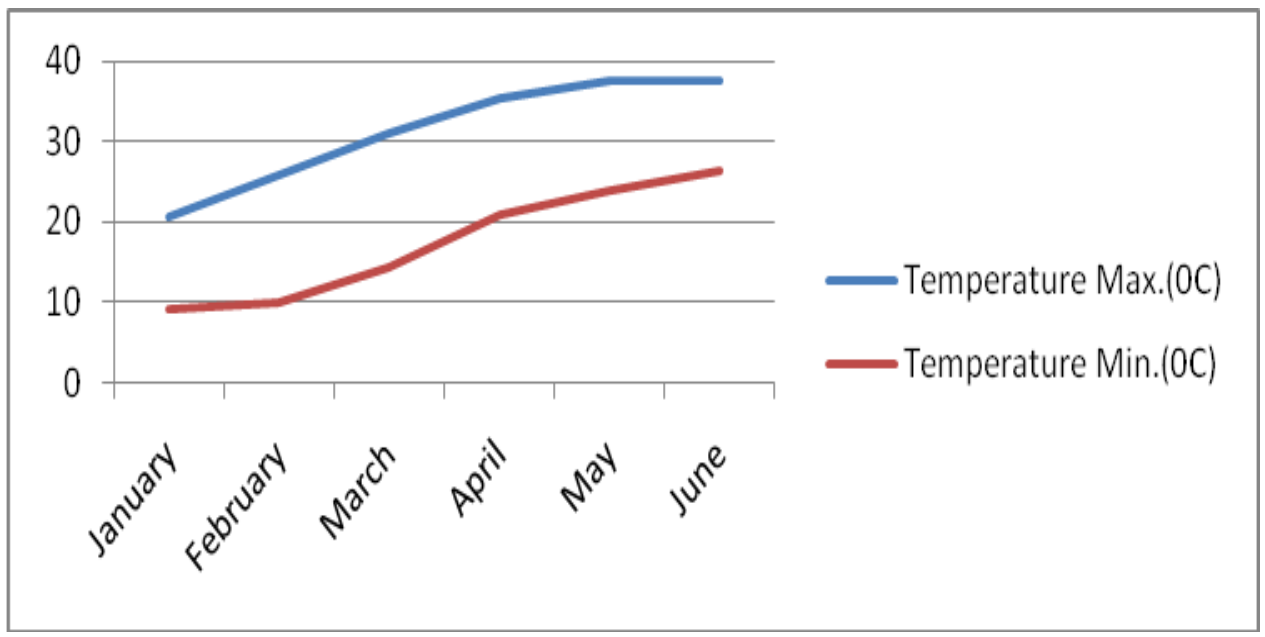

Fig.2 Relative humidity (\%) and rainfall (mm) during experimental period

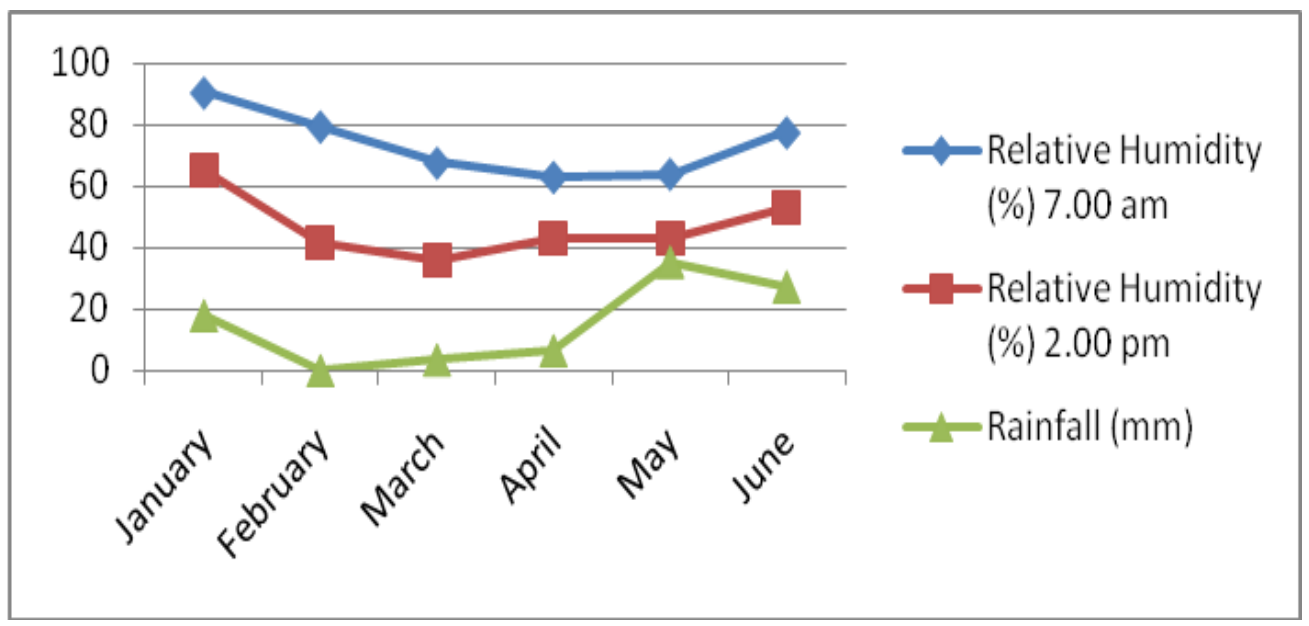

Table.1 Treatment combinations

\begin{tabular}{|c|c|c|c|c|c|c|c|c|c|}
\hline & \multicolumn{8}{|c|}{ Treatment Combination } \\
\hline \multicolumn{2}{|c|}{ Name of Treatment } & \multirow{2}{*}{$\begin{array}{c}\mathbf{N} \\
100\end{array}$} & & \multirow{2}{*}{$\begin{array}{c}\mathbf{P} \\
60\end{array}$} & \multirow[b]{2}{*}{ : } & \multirow{2}{*}{$\begin{array}{c}\mathbf{K} \\
50\end{array}$} & \multirow[b]{2}{*}{$\mathrm{x}$} & \multicolumn{2}{|c|}{ Vermicompost $\left(\mathrm{tha}^{-1}\right)$} \\
\hline $\mathrm{T}_{1}$ & $F_{1} \times V_{1}$ & & : & & & & & 4.68 & $\left.\mathrm{tha}^{-1}\right)$ \\
\hline $\mathrm{T}_{2}$ & $F_{1} \times V_{2}$ & 100 & : & 60 & : & 50 & $\mathrm{x}$ & 3.50 & $\mathrm{tha}^{-1}$ \\
\hline $\mathrm{T}_{3}$ & $\mathrm{~F}_{1} \times \mathrm{V}_{3}$ & 100 & : & 60 & : & 50 & $\mathrm{x}$ & 2.43 & $\mathrm{t} \mathrm{ha}^{-1}$ \\
\hline $\mathrm{T}_{4}$ & $F_{2} \times V_{1}$ & 75 & : & 45 & : & 37.5 & $\mathrm{x}$ & 4.68 & $\mathrm{t} \mathrm{ha}^{-1}$ \\
\hline $\mathrm{T}_{5}$ & $\mathrm{~F}_{2} \times \mathrm{V}_{2}$ & 75 & : & 45 & : & 37.5 & $\mathrm{x}$ & 3.50 & $\mathrm{tha}^{-1}$ \\
\hline $\mathrm{T}_{6}$ & $F_{2} \times V_{3}$ & 75 & : & 45 & : & 37.5 & $\mathrm{x}$ & 2.43 & $\mathrm{tha}^{-1}$ \\
\hline $\mathrm{T}_{7}$ & $F_{3} \times V_{1}$ & 50 & : & 30 & : & 25 & $\mathrm{x}$ & 4.68 & $\mathrm{t} \mathrm{ha}^{-1}$ \\
\hline $\mathrm{T}_{8}$ & $F_{3} \times V_{2}$ & 50 & : & 30 & : & 25 & $\mathrm{x}$ & 3.50 & $\mathrm{t} \mathrm{ha}^{-1}$ \\
\hline $\mathrm{T}_{9}$ & $\mathrm{~F}_{3} \times \mathrm{V}_{3}$ & 50 & : & 30 & : & 25 & $\mathrm{x}$ & 2.43 & $\mathrm{tha}^{-1}$ \\
\hline
\end{tabular}


Table.2 Effect of vermicompost, inorganic fertilizer and its interactions on growth and quality of bitter gourd

\begin{tabular}{|c|c|c|c|c|c|c|c|c|c|c|c|c|c|c|c|c|c|c|}
\hline & \multicolumn{2}{|c|}{$\begin{array}{l}\text { length of } \\
\text { main vine } \\
\text { (m). }\end{array}$} & \multicolumn{2}{|c|}{$\begin{array}{c}\text { No. of } \\
\text { branches per } \\
\text { plant }\end{array}$} & \multicolumn{2}{|c|}{$\begin{array}{l}\text { days to first } \\
\text { female flower } \\
\text { emergence }\end{array}$} & \multicolumn{2}{|c|}{$\begin{array}{l}\text { node no. to } \\
\text { first female } \\
\text { flower } \\
\text { emergence }\end{array}$} & \multicolumn{2}{|c|}{$\begin{array}{l}\text { days to first } \\
\text { fruit picking }\end{array}$} & \multicolumn{2}{|c|}{$\begin{array}{c}\text { TSS } \\
\left({ }^{0} \text { Brix. }\right)\end{array}$} & \multicolumn{2}{|c|}{$\begin{array}{c}\text { Vit C } \\
\text { (mg/100g) }\end{array}$} & \multicolumn{2}{|c|}{ Iron (\%) } & \multicolumn{2}{|c|}{ Zinc (ppm) } \\
\hline V1 & \multicolumn{2}{|c|}{4.03} & \multicolumn{2}{|c|}{8.72} & \multicolumn{2}{|c|}{49.48} & \multicolumn{2}{|c|}{13.23} & \multicolumn{2}{|c|}{59.30} & \multicolumn{2}{|c|}{5.68} & \multicolumn{2}{|c|}{78.46} & \multicolumn{2}{|c|}{0.1539} & \multicolumn{2}{|r|}{41.60} \\
\hline V2 & \multicolumn{2}{|c|}{3.82} & \multicolumn{2}{|c|}{8.17} & \multicolumn{2}{|c|}{52.31} & \multicolumn{2}{|c|}{14.05} & \multicolumn{2}{|c|}{62.78} & \multicolumn{2}{|c|}{5.29} & \multicolumn{2}{|c|}{72.03} & \multicolumn{2}{|c|}{0.1278} & \multicolumn{2}{|r|}{37.24} \\
\hline V3 & \multicolumn{2}{|c|}{3.62} & \multicolumn{2}{|c|}{7.81} & \multicolumn{2}{|c|}{53.07} & & 13.98 & & 3.69 & 4. & & 66 & & 0.1 & 349 & & 47.69 \\
\hline F1 & & 4.01 & & 8.57 & & 4.02 & & 14.22 & & 4.35 & 5. & & 65 & & 0.1 & 537 & & 39.14 \\
\hline F2 & & 3.84 & & 8.13 & & 0.58 & & 13.78 & & 1.33 & 5. & & 74 & & 0.1 & 289 & & 42.24 \\
\hline F3 & & 3.61 & & 8.01 & & 0.25 & & 13.27 & & .09 & 5. & & 77 & & 0.1 & 341 & & 45.16 \\
\hline F1XV1 & & 4.17 & & 9.05 & & 4.85 & & 14.72 & & 5.80 & 5. & & 65 & & 0.1 & 551 & & 36.73 \\
\hline F2XV1 & & 3.93 & & 8.60 & & 7.51 & & 13.20 & & 7.27 & 5. & & 81 & & 0.1 & 531 & & 47.80 \\
\hline F3XV1 & & 3.90 & & 8.52 & & 5.08 & & 1.77 & & 4.82 & 5. & & 88 & & 0.1 & 536 & & 40.27 \\
\hline F1XV2 & & 4.00 & & 8.61 & & 4.43 & & 14.30 & & 4.69 & 5. & & 66 & & 0.1 & 541 & & 37.87 \\
\hline F2XV2 & & 3.97 & & 8.04 & & 1.84 & & 13.43 & & 2.84 & 5. & & 74 & & 0.1 & 193 & & 36.73 \\
\hline F3XV2 & & 3.48 & & 7.87 & & 0.67 & & 14.33 & & .80 & 4. & & 75 & & 0. & 101 & & 37.13 \\
\hline F1XV3 & & 3.88 & & 8.06 & & 4.02 & & 13.63 & & 2.56 & 5. & & 63 & & 0.1 & 519 & & 42.83 \\
\hline F2XV3 & & 3.55 & & 7.73 & & 0.58 & & 13.70 & & 3.87 & 4. & & 66 & & 0.1 & 142 & & 42.18 \\
\hline F3XV3 & & 3.43 & & 7.64 & & 0.25 & & 13.70 & & 4.66 & 4. & & 69 & & 0.1 & 387 & & 58.07 \\
\hline & $\begin{array}{l}\mathrm{SE} \\
\mathrm{m} \pm\end{array}$ & $\begin{array}{c}\mathrm{CD}(\mathrm{P}= \\
0.05)\end{array}$ & $\begin{array}{l}\mathrm{SE} \\
\mathrm{m} \pm\end{array}$ & $\begin{array}{c}\mathrm{CD}(\mathrm{P}= \\
0.05)\end{array}$ & $\begin{array}{l}\text { SEm } \\
\pm\end{array}$ & $\begin{array}{c}\mathrm{CD}(\mathrm{P}= \\
0.05)\end{array}$ & $\begin{array}{l}\mathrm{SE} \\
\mathrm{m} \pm\end{array}$ & $\begin{array}{c}\mathrm{CD}(\mathrm{P}= \\
0.05)\end{array}$ & $\begin{array}{l}\mathrm{SE} \\
\mathrm{m} \pm\end{array}$ & $\begin{array}{c}\mathrm{CD}(\mathrm{P} \\
=0.05)\end{array}$ & $\begin{array}{l}\text { SEm } \\
\pm\end{array}$ & $\begin{array}{c}\mathrm{CD}( \\
\mathrm{P}=0 \\
05)\end{array}$ & $\begin{array}{l}\text { SEm } \\
\pm\end{array}$ & $\begin{array}{c}\mathrm{CD}( \\
\mathrm{P}=0 \\
05)\end{array}$ & $\begin{array}{l}\mathrm{SE} \\
\mathrm{m} \pm\end{array}$ & $\begin{array}{l}\mathrm{CD}(\mathrm{P} \\
=005)\end{array}$ & $\begin{array}{l}\text { SEm } \\
\quad \pm\end{array}$ & $\mathrm{CD}(\mathrm{P}=005)$ \\
\hline $\mathbf{F}$ & 0.03 & 0.10 & 0.05 & 0.15 & 0.31 & 0.92 & 0.08 & 0.24 & 0.39 & 1.17 & 0.039 & 0.117 & 0.002 & 0.006 & 0.002 & 0.006 & 0.68 & NS \\
\hline V & 0.03 & 0.10 & 0.05 & 0.15 & 0.31 & 0.92 & 0.08 & 0.24 & 0.39 & 1.17 & 0.039 & 0.117 & 0.002 & 0.006 & 0.002 & 0.006 & 0.68 & 2.03 \\
\hline FXV: & 0.01 & NS & 0.15 & $\mathrm{NS}$ & 0.92 & NS & 0.24 & 0.73 & 1.16 & NS & 0.117 & NS & 0.006 & NS & 0.006 & NS & 2.03 & 6.08 \\
\hline
\end{tabular}


Table.3 Effect of vermicompost, inorganic fertilizer and its interactions on yield and economics of bitter gourd

\begin{tabular}{|c|c|c|c|c|c|c|c|c|c|c|c|c|c|c|c|c|c|c|}
\hline & \multicolumn{2}{|c|}{$\begin{array}{l}\text { number of } \\
\text { fruits per vine. }\end{array}$} & \multicolumn{2}{|c|}{$\begin{array}{l}\text { fruit length } \\
\qquad(\mathrm{cm}) .\end{array}$} & \multicolumn{2}{|c|}{$\begin{array}{l}\text { fruit girth } \\
\qquad(\mathrm{cm}) .\end{array}$} & \multicolumn{2}{|c|}{$\begin{array}{l}\text { average fruit } \\
\text { weight }(\mathrm{g}) \text {. }\end{array}$} & \multicolumn{2}{|c|}{$\begin{array}{c}\text { fruit weight } \\
\text { per vine }(\mathrm{kg}) \text {. }\end{array}$} & \multicolumn{2}{|c|}{$\begin{array}{c}\text { fruit yield } \\
\text { (t/ha) of bitter } \\
\text { gourd. }\end{array}$} & \multicolumn{2}{|c|}{$\begin{array}{l}\text { Gross income.(Rs. } \\
\text { ha }^{-1} \text { ) }\end{array}$} & \multicolumn{2}{|c|}{$\begin{array}{l}\text { Net income. (Rs. } \\
\text { ha }^{-1} \text { ) }\end{array}$} & \multicolumn{2}{|c|}{ B:C ratios } \\
\hline V1 & \multicolumn{2}{|r|}{62.86} & \multicolumn{2}{|c|}{13.82} & \multicolumn{2}{|c|}{8.41} & \multicolumn{2}{|c|}{62.18} & \multicolumn{2}{|c|}{3.99} & \multicolumn{2}{|c|}{31.91} & \multicolumn{2}{|c|}{223340.44} & \multicolumn{2}{|c|}{153172.34} & \multicolumn{2}{|c|}{2.19} \\
\hline V2 & \multicolumn{2}{|r|}{62.70} & \multicolumn{2}{|c|}{12.85} & \multicolumn{2}{|c|}{8.01} & \multicolumn{2}{|c|}{58.70} & \multicolumn{2}{|c|}{3.76} & \multicolumn{2}{|c|}{30.11} & \multicolumn{2}{|c|}{210777.78} & \multicolumn{2}{|c|}{147647.68} & \multicolumn{2}{|c|}{2.34} \\
\hline V3 & \multicolumn{2}{|r|}{55.32} & \multicolumn{2}{|c|}{11.95} & \multicolumn{2}{|c|}{7.88} & & .57 & & .25 & & 5.98 & 181 & 32.00 & 1251 & 87.90 & & \\
\hline F1 & & 61.81 & & 2.46 & & .35 & 56 & .75 & & .64 & & 9.14 & 203 & 54.44 & 1393 & 95.61 & & \\
\hline F2 & & 56.78 & & 3.53 & & .10 & 60 & .71 & & .52 & & 8.18 & 197 & 44.44 & 1339 & 30.35 & & \\
\hline F3 & & 62.29 & & 2.62 & & .85 & & .98 & & .83 & & 0.68 & 214 & 41.33 & 1526 & 81.95 & & \\
\hline F1XV1 & & 56.18 & & 3.20 & & .53 & & .75 & & .20 & & 5.63 & 181 & 32.00 & 1079 & 63.84 & & \\
\hline F2XV1 & & 63.93 & & 3.83 & & .35 & 64 & .88 & & .16 & & 3.28 & 181 & 32.00 & 1627 & 73.24 & & \\
\hline F3XV1 & & 68.47 & & 4.43 & & .33 & & .91 & & .60 & & 6.81 & 181 & 32.00 & 1887 & 79.95 & & \\
\hline F1XV2 & & 65.36 & & 2.84 & & .33 & 57 & .73 & & .02 & & 2.16 & 225 & 01.33 & 1607 & 16.50 & & \\
\hline F2XV2 & & 55.35 & & 3.78 & & .02 & 57 & .02 & & .22 & & 5.72 & 180 & 58.67 & 1169 & 28.58 & & \\
\hline F3XV2 & & 67.40 & & 1.92 & & .69 & & .34 & & .06 & & 2.45 & 227 & 73.33 & 1652 & 97.95 & & \\
\hline F1XV3 & & 63.89 & & 1.34 & & .18 & & .77 & & .70 & & 9.63 & 207 & 5.33 & 1495 & 06.50 & & \\
\hline F2XV3 & & 51.06 & & 2.99 & & .93 & & .24 & & 19 & & 5.53 & 178 & 33.33 & 1220 & 89.24 & & \\
\hline F3XV3 & & 51.00 & & 1.51 & & .53 & & .70 & & .85 & & 2.77 & 159 & 57.33 & 1039 & 67.95 & & \\
\hline & SEm \pm & $\begin{array}{c}C D \\
(P=0.05)\end{array}$ & SEm \pm & $\begin{array}{c}C D \\
(P=0.05)\end{array}$ & SEm \pm & $\begin{array}{c}C D \\
(\mathrm{P}=005)\end{array}$ & SEm \pm & $\begin{array}{c}C D \\
(P=005)\end{array}$ & SEm \pm & $\begin{array}{c}C D \\
(\mathrm{P}=005)\end{array}$ & SEm \pm & $\begin{array}{c}C D \\
(P=005)\end{array}$ & SEm \pm & $\begin{array}{c}C D \\
(P=0.05)\end{array}$ & SEm \pm & $\begin{array}{c}C D \\
(\mathrm{P}=0.05)\end{array}$ & SEm \pm & $\begin{array}{c}\mathrm{CD} \\
(\mathrm{P}=005)\end{array}$ \\
\hline $\mathbf{F}$ & 0.48 & 1.45 & 0.11 & NS & 0.045 & NS & 0.39 & 1.18 & 0.03 & 0.08 & 0.22 & 0.65 & 1514.86 & 4540.88 & 1514.86 & 4540.88 & 0.024 & 0.073 \\
\hline V & 0.48 & 1.45 & 0.11 & 0.34 & 0.045 & 0.14 & 0.39 & 1.18 & 0.03 & 0.08 & 0.22 & 0.65 & 1514.86 & 4540.88 & 1514.86 & 4540.88 & 0.024 & NS \\
\hline FXV: & 1.45 & 4.36 & 0.34 & NS & 0.136 & NS & 1.18 & 3.54 & 0.08 & 0.24 & 0.65 & 1.95 & 4544.59 & 4540.88 & 4544.59 & 13622.63 & 0.073 & 0.219 \\
\hline
\end{tabular}


These findings are closely related to those Sreenivas et al., (2000) in ridge gourd, Kodzeij \& Kosteckaj (1994) in cucumber. Application of vermicompost 100 per cent significantly improved the iron $(0.1539 \%)$ content in the fruit. Increase in various parameters in fruits with higher doses of vermicompost might be due to increase in the available micro and macro nutrients (Kale et al., 1992) and (Giraddi, 1993). Application of vermicompost showed significant influence on zinc $(\mathrm{Zn})$ content in fruit. Each increasing doses of vermicompost significantly decreased the zinc $(\mathrm{Zn})$ content in fruit and recorded maximum zinc $(\mathrm{Zn})$ concentration $(42.83 \mathrm{ppm})$ under applied 50 per cent vermicompost. Minimum zinc ( $\mathrm{Zn})$ content (36.73 ppm) in fruit was recorded under vermicompost @ 100 per cent. In the present investigation application of vermicompost 50 $\%$ significantly increased $\mathrm{Zn}$ content because of low content of phosphorus, higher $\mathrm{P}_{2} \mathrm{O}_{5}$ causes antagonistic effect on Zinc ( $\mathrm{Zn}$ ) ion absorption. Similar finding was observed by (Aroiee and Omidbagi, 2004) in medicinal pumpkin. Application of vermicompost 100 per cent significantly increased the gross income (Rs. 223340.44 ha ${ }^{-1}$ ) and net income (Rs. 153172.34). Significant increase the gross income and net profit with application of higher vermicompost in the present investigation may be because of the increase in the yield and reduced production cost.

The growth attributes like main vine length $(4.01 \mathrm{~m})$ and number of branches (8.57) increased significantly due to the application of 100 percent inorganic fertilizer. Minimum node number to first female flower emergence (13.27), days taken to first female flower emergence (50.25), days to first fruit picking (60.09) were recorded under lowest dose i.e. 50 per cent of inorganic fertilizer. This might be because higher dose of inorganic fertilizer (NPK) promotes vegetative growth \& improves vegetation and delays flower initiation and application of lower dose of inorganic fertilizer i.e. @ 50 per cent might have provided balanced nutrition and brought better growth, development and promoted timely flower initiation in plants. Similar findings have also been reported by the Reddy et al., (2004) in bitter gourd, Kameshwari et al., (2011) in ridge gourd, Singh et al., (2012) in bottle gourd, Srinivass et al., (2000) in cucumber, Obyese et al., (2013) in pumpkin. Number of fruit per plant, average single fruit yield $(61.98 \mathrm{~g})$, fruit weight per vine $(3.83 \mathrm{~kg}$ per plant), yield $\left(30 \mathrm{t} \mathrm{ha}^{-1}\right)$ significantly increased with application of 50 per cent inorganic fertilizer. The progressive increase in number of fruits per plant, fruit weight and fruit yield $\left(\mathrm{t} \mathrm{ha} \mathrm{h}^{-1}\right)$ might be due to the optimum dose of NPK, which accelerated mobility of photosynthesis from the source to the sink as influenced by the growth hormone, and NPK uptake. These finding are in agreement with the findings of Umamhaswrappah (2004) in Bottle gourd, Cheema et al., (2001) and Hocking et al., (2003) in canola, Jillani et al., (2009) and Prabhu et al., (2003) in cucumber. Total Soluble Solids $\left(5.50^{\circ}\right.$ Brix), in fruit was significantly improved by the application of inorganic fertilizer @ 100 per cent. Ascorbic acid (77.89 mg $100 \mathrm{~g}^{-1}$ fresh fruit weight) content was higher in treatment 50 per cent inorganic fertilizer followed by 75 per cent inorganic fertilizer $\left(74.13 \mathrm{mg} \quad 100 \mathrm{~g}^{-1}\right)$. Increasing level of inorganic fertilize reduced vitamin "C" content because when a plant is exposed with nitrogen it increases protein production and reduced carbohydrate synthesis since vitamin $\mathrm{C}$ is synthesized from carbohydrates. Similar results have also obtained by Meenakshi et al., (2007) in bitter gourd, Shweta et al., (2007) in tomato. Application of inorganic fertilizer @ 50 per cent recorded maximum net profit i.e., 152681.95 (Rs./ha) with higher benefit: cost ratio (2.43) which was found most outstanding treatment. These higher B: C ratio 
was mainly due to lower cost of cultivation with the use of lower level of inorganic fertilizer and producing higher yield in comparison to remaining level. These results are also in conformity with the findings of Kameshwari et al., (2009) in cucumber and Vijay Kumar et al., (2012) in bottle gourd and Dewangen (2012) in bottle gourd.

Combine use of vermicompost and NPK fertilizer showed significant influence in case of number of nodes to first female flower, no. of fruits per vine, fruit weight $(\mathrm{kg})$ per vine, yield $\left(\mathrm{t} \mathrm{ha}{ }^{-1}\right)$,gross income, net income, and $\mathrm{B}: \mathrm{C}$ ratio, Among the quality characters, significant effect due vermicompost and NPK fertilizer interaction was observed in case of zinc content in fruit (ppm).The minimum node number to first female flower emergence (11.77) was noticed under the combined use of inorganic fertilizer @ 50 per cent and vermicompost @ 100 per cent. Maximum node number (14.72) was recorded under $\mathrm{F}_{1} \mathrm{x}$ $\mathrm{V}_{1}$ vermicompost. It might be due to the fact that the plants in the presence of inorganic nutrients (NPK) along with vermicompost probably regulated the plant physiological and morphological functions which resulted in completion of the vegetative growth at faster rate and as a result, plant entered into the reproductive phase earlier which caused the first female flower to appear at lesser node number. The results of the present investigation have similarity with the findings reported earlier by Rai et al., (2012), Kameswari et al., (2011) in cucumber, Vijay Kumar et al., (2012) in bottle gourd, Dewagan (2012) in bottle gourd. The plants developed under NPK fertilizer 50 per cent and vermicompost 100 per cent significantly produced higher number of fruits per vine (68.47) and average fruit weight. The maximum fruit yield per vine $(4.60 \mathrm{~kg}$ per vine and) yield (36.81t ha $\mathrm{ha}^{-1}$ ) was attained under the combined use of vermicompost @ 100 per cent and inorganic fertilizer (NPK) @
50 per cent, which was superior to vermicompost 100 per cent $\mathrm{x}$ inorganic fertilizer 75 per cent, vermicompost 75 per cent $\mathrm{x}$ inorganic fertilizer 50 per cent and vermicompost 75 per cent $x$ inorganic fertilizer 100 per cent. The results summarized above in respect of number of fruits per vine and average fruit weight and average yield of fruits ( $t$ per ha) are in consonance with the findings reported earlier by Anuja and Poovizhi (2009) in cucumber and Kameswari et al., (2010) in sponge gourd, Vijay et al., (2012) and Dewagan (2012) in bottle gourd. Wang et al., (2010) in Chinese cabbage, and Atiyeh et al., (2001) in marigold. Maximum zinc content i.e., 58.07 ppm was noticed under the combine use of vermicompost @ 50 per cent x inorganic fertilizer @ 50 per cent which was significantly superior to all other combinations.

The gross income, net profit and $\mathrm{B}$ : $\mathrm{C}$ ratio was markedly affected due to different sources of nutrients and recorded maximum values under the application of vermicompost@4.68 t ha ${ }^{-1}$ and 50:30:25kg NPK (50\% fertility level). The higher gross income under 100 per cent vermicompost $\mathrm{x}$ 50 per cent fertilizer level was mainly due to higher yield, while enhanced net income and benefit: cost ratios was because the cost of cultivation involved in the production was minimum under this treatment combination. These results are also in conformity with findings of Vijay Kumar et al., (2012) in bottle gourd, Kameswari et al., (2010), and Dewangen, (2012) in bottle gourd.

On the basis of above discussions it may be concluded that, the application of 100 per cent vermicompost (4.68 $\mathrm{t} \mathrm{ha}^{-1}$ ) and combination with 50 per cent of inorganic fertilizer was found to be most effective treatment combination for getting higher yield and maximum net return. 


\section{Acknowledgement}

The authors acknowledge Chairman, Department of Horticulture (Vegetable and Floriculture), Bihar Agricultural College, Bihar Agricultural University, Sabour, India, for their invaluable guidelines and support as well as for providing all the infrastructure and facilities required for research purposes. The authors are also thankful to the scientists whose published work has been freely cited in this research paper.

\section{References}

Anuja, S., and Poovizhi, K. 2009. Effect of organic nutrient son yield and yield attributes of cucumber (Cucumis sativus) cv. Long green, Vegetable Science 6 (2): 163-166

Arancon, N. Q., Edwards, C. A., and Bierman, P. 2006. Influences of vermicompost on field of strawberries: part-2 effects on soil microbial and chemical properties. Bio-resource Technology 97: 831-840.

Aroiee, H., and Omidbaigi, R. 2004.Effect of nitrogen fertilizer on productivity of medicinal pumpkin. Acta Horticulture 629.

Atiyeh, R. M., Arancon, N.Q., Edwards, C. A. and Metzger, J. D. 2001. The influence of earthworm-processed pig manure on the growth and productivity of marigolds. Bio-resource Technology 81: 103-108.

Azarmi R., Giglou, M. T., and Taleshmikail, R. D. 2008. Influence of vermicompost on soil chemical and physical properties in tomato field. African $J$. of Biotechnology, 7 (14): 2397-2401.

Behera T.K., Sureja, A. K., Sabina, Islam, Munshi, A. D., and Sidhu, A. S. 2011. Minor cucurbits. Genetics, genomics and breeding of cucurbits1760.
Cheema, M. A., Malik, M. A., Hussain, A., Sah, S. H., and, Basra, M. A. 2001. Effects of time and rate of nitrogen and phosphorous application on the growth and the seed and oil yield of Canola (Brassica napus L.). Jr. of Agron. And Crop. Sc., 186 (2): 106-110.

Devangen, M.K. 2012.Studies on integrated nutrient management on growth and yield of bottle gourd [Lagenariasic eraria (Mol.) Standl.]. M. Sc. Ag. thesis of B.A.U. Sabour, Department of Horticulture (Veg. and Flori.).

Hidalgo, P. 1999. Earthworm castings increase germination rate and seedling development of cucumber. Mississippi and Forestry Experiment Station, Research Report, 22 No. 6.

Hocking, P. J., Mead, J. A., Good, A. J., and Diffey, S. M. 2003.The response of Canola (Brassica napus L.) to tillage and fertilizer placement in contrasting environments in Southern New South Wales. Aust. J. of Exp. Agriculture, 43(11): 1323-1333.

Jilan, M. S., Afzaal, M. F., and Waseem, K. 2008. Effect of different nitrogen levels on growth and yield of brinjal. J. Agric. Res., 46: 245-251.

Kale, R. D., Mallesh, B., Bano,C. K., and Bagyaraj, D. J. 1992. Influence of vermicompost application on the available macro-nutrients and selected microbial population in a paddy field. Soil Biol. Biochem, 24 (12): 1317-1320.

Kameswari, M., Lalitha, P., Narayanamma, S., Riazuddin, A., and Charturvedi, A. 2011. Influence of integrated nutrient management in ridge gourd [Luffa acutangula (Roxb.) L.]. Vegetable Science, 38(2): 209-211.

Koodzeij, M., and Kostecka, J., 1994.Some quality characteristics in cucumbers and carrots grown on vermicompsts.ZezytyNaukeme-Akademii-Roluicoz-ej-im- 
Hugona-Katoja-w.Karkowie, SerjaNaakowa, 41: 89-93

Kumar, N., Sowmyamala, K. S., Kumar, S., Vasudev, B. V., Vasantha, P. G., Kumar, P. N. R., and Nagaraj, H. T. 2012. Effect of plant growth promoting rhizobacteria (PGPR) on growth and yield of bitter gourd. IJABPT. 3(1): 1-6.

Kumar, V., Singh, V. K., and Rani, T. 2012. Effect of integrated nutrient management on economics in bottle gourd (Langenaria siceraria L.). Environmental \& Ecology, 30 (4A): 1410-1412.

Ludwick A E, and Johnstone A M 2002. Organic nutrients. Better Crops, 86: 810

MarilouMante, Benitez and Constancio, C De Guzman 2012. Antioxident content of bitter gourd (Momordica charantia L.) grown in different nutrient amendments. International annual symposium on sustainability science and management.

Meenakshi, N., Vadivel, E., and Kavitha, M. 2007. Response of bitter gourd (Momordica charantia L.) on fruit yield and quality traits as influenced by fertigation levels. The Asian Journal of Horticulture, 2(2): 126-130.

Narkhede, S. D., Attarde, S. B., and Ingle, S. T., 2011. Study on effect chemical fertilizer and vermicompost on growth of chilli pepper plant (Capsicum annum). Journal of applied science. in environmental sanitation, 6 (3): 327332.

Obyese, F. M., Agbaje, G. O., and Obisesan, I. O. 2013. Effect of NPK Fertilizer on Fruit Development of Pumpkin (Cucurbita pepo Linn.). American J. of Experimental Agriculture 3(2): 403411/ www.sciencedomain.org.

Panse, V. G., and Sukatme, P. V. 1978. Statistical methods for agricultural workers. ICAR publications, New Delhi, Pp. 225.
Prabha, K. P., Loretta, Y.L., and Usha, R. K. 2007. An experimental study of verminbio waste composting for agricultural soil improvement. Bio resource Technology, 99: 1672-1681

Prabhu M, Natarajan S, Srinivasan K and Pugalendhi L 2006. Integrated nutrient management in cucumber, Indian $J$. Agriculture Research 40 (2): 123 - 126.

Prasad, P. H., Mandal, A. R., Sarkar, A., Thapa, U. and Maity, T. K.2009.Effect of Bio-Fertilizers and Nitrogen on Growth and Yield Attributes of Bitter gourd (Momordic acharantia L.). International Conference on Horticulture. pp. 738-739.

Rai, R., Thapa, U., Mandal, A. R. and Roy, B. 2012. Growth, yield and quality of Cabbage (Brassica olerace Var Capitata L.) as influenced by vermicompost. Environment and Ecology, 31 (1A): 314-317. environmentachnology.com

Reddy, P. K., and Rao, P.V. 2004. Growth and yield of bitter gourd (Momordica charantia L.) as influenced by vermicompost and nitrogen management practices. Journal of Research ANGRAU 32 (3):15-20.

Renuka, B., and Ravishankar., C. 2001. Effect of organic manures on growth and yield of tomato. South Indian Horticulture, 49: 216-219.

Shweta, S., and Sharma, D. 2007. Enhancing nutrients in tomato Lycopersicon esculentum Mill.) through vermicomposting. Phyto medicines, Recent Progress in Medicinal Plants, 1: 6623-627.

Singh, D. P., Mishra, U. C., Prakash, H. G., and Mishra, O. 2012. Role of organic farming on yield and economics of bottle gourd and vegetable pea. International Journal of Agricultural Sciences, 8(1): 165-167.

Sreenivas, C., Muralidhar, S. and Rao, M. S. 2000. Yield and quality of ridge gourd 
fruits as influenced by different levels of inorganic fertilizers and vermicompost. Annals of Agricultural Research, 21 (2): 262-266.

Umamaheswarappa, P., Krishnappa, K. S., Murthy, P. V., Nagarajappa, A., and. Muthu, M. P. 2004. Uptake of NPK by plant and leaf chlorophyll content of bottle gourd cv Arka Bahar as influenced by various levels of N, P and
K. Environment and Ecology, 22: 653656.

Wang, D., Shi, Q., Wang, X., Wei, M., Hu, J., Liu, J., and Yang, F. 2010. Influence of cow manure vermicompost on the growth, metabolite contents, and antioxidant activities of Chinese cabbage (Brassica campestris ssp. chinensis). Biol. Fertil. Soils, 46: 689696.

\section{How to cite this article:}

Sangeeta Shree, Champa Lal Regar, Fiza Ahmad, Vijay Kumar Singh, Ritu Kumari and Amrita Kumari. 2018. Effect of Organic and Inorganic Fertilizers on Growth, Yield and Quality Attributes of Hybrid bitter gourd (Momordica charantia L.). Int.J.Curr.Microbiol.App.Sci. 7(04): 2256-2266. doi: https://doi.org/10.20546/ijcmas.2018.704.258 